\title{
The role of the community in the implementation of one roof school
}

\author{
Wiwik Wijayanti \\ Universitas Negeri Yogyakarta. Jalan Colombo No. 1, Yogyakarta 55281, Indonesia \\ * Corresponding Author. Email: wiwik_wijayanti@uny.ac.id
}

Received: 11 February 2020; Revised: 2 March 2020; Accepted: 7 March 2020

\begin{abstract}
This study aims to describe the role of the community in the implementation of a one-roof junior high school. One-roof junior high school (one-roof school) is a new school unit in an isolated and isolated area. In this area the public interest is still low, it is necessary to bring the closest junior high school to the nearest elementary school so that the surrounding elementary school graduates can continue to junior high school. To reveal the role of the community, a qualitative approach is used. The subjects in this study were obtained by snowball sampling technique; consisting of students' parents, the local village community, students, teachers, school principals, head of UPT and head of the Basic Education Section. Data collection techniques carried out by interviews, observation and study of documents, the validity of the data obtained by the test of credibility, transferability, dependability and confirmability. Then the data are analyzed using the Interactive model. The results of this study indicate that; First, stakeholders act according to their portion; Second, parents have the awareness of sending them to school and encouraging their children to want to continue schooling; Third, the surrounding community participates in the construction of buildings, collaborating to contribute labor; sub-standard wage agreements, as a form of community awareness and contribution to the One Roof Junior Secondary School; Fourth, student participation is needed in organizing the learning process and school development plans; Fifth, teachers work together and carry out tasks according to their authority; Sixth, the Principal coordinates the activities in elementary and junior high schools; Seventh, the Head of UPT facilitated the process of proposing the establishment of SMP; Eighth, Head of the Elementary and Secondary Education Section as a consultant in the implementation of the One Roof Junior Secondary School.
\end{abstract}

Keywords: community participation, total football, positive deviation and one-roof school

How to Cite: Wijayanti, W. (2020). The role of the community in the implementation of one roof school. Jurnal Prima Edukasia, 8(1), 1-11. doi:https://doi.org/10.21831/jpe.v8i1.30134

\section{Introduction}

Basic education is a general education for six years to nine years. Various references mention that basic education is an educational foundation to prepare students to become citizens who have faith and piety, able to carry out the obligations as a citizen, and have basic skills for all jobs in a society (Bafadal, 2007 , p. 8). In essence, education is a conscious and planned effort in realizing the learning process for students to actively develop their potential so that they become human beings who have the spiritual religious strength, good personality, intelligence, and skills needed by themselves, the community, the nation and the country (Undang-Undang Republik Indonesia nomor 20 tahun 2003 tentang sistem pendidikan nasional, 2003). The core concept of education is to realize the learning process that can facilitate students. Thus, they have the opportunity to develop their potential, ranging from the potential of divinity understanding, personality, health, intelligence, and skills. The purpose of education is to guide students in the process by which they shape themselves as human persons, armed with knowledge and decision-making power, and moral virtue, at the same time, delivered to they are the spiritual heritage of the nation and civilization where they are involved are implemented (Darmayanti \& Wibowo, 2014). The ultimate goal of education is the development of the students' potential, so that they are able to be proper human beings who believe and fear God Almighty, have noble personality, broad insight, healthy physical and spiritual state, and skills needed by the students themselves, society, and the nation. Therefore, education is not only the interests of the students but also the society, and the nation. 
Jurnal Prima Edukasia, 8 (1), 2020 - 2

Wiwik Wijayanti

From the various goals mentioned above, the purpose of basic education is to equip students with the required knowledge, skills and positive attitude. The required knowledge includes the knowledge of health, social, local culture, and citizenship. The required skills include reading, writing and arithmetic skills. Meanwhile, the positive attitudes needed include independence, courage, responsibility and enthusiasm for learning. Knowledge, skills and positive attitudes are needed by students in their lives, so they can possess the equal rights of life and the opportunity to continue their education at the higher level.

Highlighting the problems that accompany this compulsory education, (Abu-Duhou \& Fadjar, 2002) claims that the urgent issues to be addressed were the limited of capacity for junior high schools, high dropout rates, low quality of basic education, low participation of certain community groups and lack of coordination at the local level. The solution to the problems which can be sought by the Ministry of National Education is to try to build New Class Units (NCU) in various regions, renovate elementary and junior high school buildings, hire teachers, merge elementary schools and one-roof elementaryjunior high school programs.

Within the framework of 9 (nine) year of basic compulsory education program which must be completed in 2008/2009, the Ministry of National Education, in this case the Directorate General of Primary and Secondary Education Management implemented several alternative programs to increase the Gross Enrollment Rate (GER) in regions with the lowest participation rate. One of the efforts made to increase the participation rate was by expanding access to education. The alternative programs carried out in addition to the construction of the New School Unit (NSU) and New Classrooms (NC) in schools that were over-capacity, was the One Roof Elementary-Junior High School Development Program for remote, scattered and isolated areas (Departemen Pendidikan Nasional Republik Indonesia, 2007).

In the area of Magelang Regency, the existence of the One Roof Elementary-Junior High School was officially established in July 2006. By the third year, there were still many obstacles in its implementation, not only related to the matter of the lack of interest from the community, but also the matter of limited financial support, careless management, the difficult state of the teachers in which they did not have clear view about their status and welfare, and the low level of community involvement in the implementation of one-roof schools. Low public interest in continuing education to junior high school as an indicator of lack of community participation. How is the involvement of the community in organizing a one-roof school as the main focus in this research.

The purpose of this study is to describe the role of stakeholders in the implementation of One Roof Elementary School-SMP which includes: (a) parents of students; (b) communities around the SSA; (c) school committees; (d) students; (e) teachers; (f) principals; (g) Head of District Basic Education Section; and (h) Head of District UPT.

Education is a shared responsibility between the government, parents and the community. Without community support, education cannot succeed optimally. Tilaar (2000) claims that "educational policies made and implemented are intended to provide services to stakeholders. Furthermore, the socalled stakeholders are: (1) students; (2) parents; (3) teachers; (4) education managers; and (5) central and regional governments. They are all involved in education.

Now almost all schools have school committees who are taken from the community representatives to help schools, because people from various socioeconomic levels are aware of how important their support is for successful learning at schools. Based on the results of the interview there are actually many types of community support for schools. However up to this moment, the support has been more in the physical and material elements, such as helping with the construction building, renovating schools, repairing roof tiles, and so on. Communities can also help in the educational technical fields, among others; becoming complementary teachers, other sources of information, substitute teachers; teaching local culture, specified skills; or introducing specific local traditions. However, this has not yet been realized for various reasons.

Basically, modest or wealthy people, from the upper class, middle class or lower class, have the same potential in helping schools that provide learning for their children. However, this depends on how the school approaches the community. Therefore, schools must understand how to encourage community participation so the community members are willing to help the school.

Sutisna (1993, p. 145) also suggests that the purpose of school building relations with the community are: (a) to develop an understanding of the main goals and suggestions of the school; (b) to assess school programs; (c) to unite parents of students and teachers in meeting for the students' needs; 
Jurnal Prima Edukasia, 8 (1), 2020 - 3

Wiwik Wijayanti

(d) to develop awareness about the importance of education at school in this development era; (e) to build and maintain community trust in schools; (f) to inform the community about school tasks; (g) to mobilize support and assistance for the maintenance and improvement of school programs.

To empower and enhance the role of communities, schools should be able to foster cooperation with parents and the community, create advantageous and favorable atmosphere for the students and the school community. In participatory management that involves community participation, all policies and decisions are made in collaboration to achieve mutual success. Thus, the principle of independence in a sense of togetherness is fulfilled, and this is the application of the principles mentioned as total quality management, through a mechanism known as the conception of total football by emphasizing the synergistic mobilization of forces that leads to one goal, namely improving quality and suitability of education with community development.

For the community that has realized and understood the importance of education, they assume that community and the environment empowerment are essential. However, it does not mean that for people who are still unaware of the importance of education, relationship with them is not necessary to be built. In communities that are less aware of the importance of education, schools are demanded to be more active and creative in developing more harmonious cooperative relations. In this way school performance can be improved and the implementation of educational processes at schools can be conducted productively, effectively and efficiently. Therefore, they can create productive and highquality graduates.

\section{Method}

This study uses a "multisite" design. The main characteristic of the multisite study is that researchers studied two or three even more subjects which have the same characteristic at the same time. Multisite study was chosen because it was in accordance with the research objectives, which was to obtain a detailed and comprehensive description of the implementation of the One Roof ElementaryJunior High School in Bandungrejo (Ngablak sub district), Warangan (Pakis sub district) dan Wonolelo (Sawangan sub district). The three research subjects possessed the same characteristics in many respects, such as geographical, livelihood, social and cultural conditions. The highlighted information in this study was the similarities of the three sites that from them new theories could be formulated in relation to the policy implementation. The emphasis on the equality of site settings is a characteristic multisite study.

This research was conducted in 2009, in 3 (three) One-roof Elementary-Junior High School, which were in the region of Bandungrejo (Ngablak sub district) as site 1, Warangan (Pakis sub district) as site 2, and Wonolelo (Sawangan sub district) as site 3. These three schools had several similarities; they were located on the slopes of Mount Merbabu, the livelihoods of surrounding communities were farmers and farm laborers, the students were from lower class families, the students came from nearby elementary schools, there was no selection in the admission of new students, the principal was originally the head of an elementary school, the learning curriculum used the regular junior high school curriculum and the teaching and educational staff were local people. What were examined in this research were the planning process, the socialization process, the implementation process and the roles of stakeholders. In accordance with the understanding of the focuses above, cross-site analysis was then employed to understand the similarities of the three sites, even though differences were possible to occur.

As stated by Bogdan and Biklen (2003) that multisite study design is a form of qualitative research design that can indeed be used primarily for the development of thoughts raised from several research sites so that to new theories can be formulated. Subsequently Bogdan and Biklen (2003) claim that multisite approach has two types of studies namely modified analytic induction and the constant comparative method. This study used a constant comparative method.

Comparative method was employed for this study, with the following steps; first the data were collected in relation to the focus category on the One-roof Elementary-Junior High School in Ngablak sub-district. Then the results were analyzed to produce a short-term theory about the implementation of Ngablak One-roof Elementary-Junior High School. Then, the collection of data on the second site was carried out, which was in One-roof Elementary-Junior High School Pakis sub-district, the results were analyzed, then compared to the temporary theory of the implementation of the One-roof ElementaryJunior High School on the first site (Ngablak). Following that the collection of data at the third site was 
Jurnal Prima Edukasia, 8 (1), 2020 - 4

Wiwik Wijayanti

conducted, which was in One Roof Elementary-Junior High School Sawangan sub-district, the results were analyzed and compared to the temporary theory of the implementation of the One Roof SD-SMP One Roof at the first site (Ngablak) and the second site (Pakis) One-roof School. The data collection was carried out repeatedly and intermittently on the three sites according to the focus category meanwhile the data were compared continuously and new events were observed until the decision to stop was reached because the saturation point had been reached. Thus, a solid theory was obtained related to the implementation of the One Roof Elementary-Junior High School.

In line with the multisite research design, this study pursues to understand the meaning of events and people's interactions in certain situations. To be able to understand the meaning of events and people's interactions, a theoretical orientation or theoretical perspective was employed with a phenomenological approach.

The data source in this study consisted of 3 heads of the District Education Unit, 3 heads of the one roof elementary-junior high school, 3 heads of the village, 6 village officials, 10 residents around the one-roof elementary school, 25 elementary-junior high school teachers The roof, and 15 students. The sources of data in the form of activities were obtained by conducting observation of their behavior in welcoming One-roof Elementary-Junior High School. For example, the teachers were observed for their behavior in teaching, the community members were observed on how they encourage their children to go to school, students were observed for their behavior in learning. Meanwhile the data source in the form of paper, the researchers synchronized what people said with the documents found. For example, regarding the teachers' academic diploma, the school principal said that everyone had appropriate academic background, and the researcher checked the teacher's data documents to ensure it.

Analysis of the data in this study is presented in two stages, namely: (a) on the site data analysis, and (b) cross-site data analysis. The analysis of the on the site data refers to the data analysis in each setting (One-roof School of Bandungrejo Ngablak sub-district, One-roof School of Warangan Pakis subdistrict and One-roof School of Wonolelo Sawangan sub-district). The data analysis, as suggested by (Bogdan \& Biklen, 2003; Miles et al., 2014) and Schlegel (1984), started at the same time as the data collection. This was done to facilitate the drawing of the tentative conclusions and findings. Then, they were then converted to matrixes and context charts as developed by Miles et al. (2014). Cross-site data analysis was intended as a process to compare the findings obtained from each of the sites, as well as integrating processes between sites with the constant comparative method.

In the qualitative approach, the research instrument is the researcher himself (Guba \& Lincoln, 2004). Therefore, it is possible that in the implementation of the study the researcher goes native or biases (Lofland \& Lofland, 1984; 50) occur. To avoid this, validity test of the data had to be employed (Lincoln \& Guba, 1985). This aims to prove that what is observed by researchers, are in accordance with what actually exists in the world of reality, and in accordance with what actually exists and occurs. The validity of the data in qualitative research is used to meet the requirement that the data and information collected by researchers contain an emic truth value, both for critical readers and for the subjects studied (Sugiyono, 2005).

To check or verify the validity of data, Moleong (2013) has four (4) techniques, namely: credibility, transferability, dependability and confirmability . Credibility is used to prove that of data of the implementation of One-roof School or information obtained from multiple sources in the field actually contain the truth value. By referring to the statement of Lincoln and Guba (1985), the level of trustworthiness of this research was fulfilled by doing the followings: (1) extending research time as an anticipatory step considering that the researcher was an outsider from the schools or the research locations that made it relatively difficult to meet the sources of the data, especially officials, for the purpose of collecting data or information from them, (2) conducting in-depth observations of various One-roof School of policy implementation activities. This technique refers to the theory stating that "the more diligent a researcher does the observation, the deeper will she/he gets the information needed". In other words, if the researcher is more meticulous in conducting observations in three locations, it will significantly minimize errors, such as carelessness in observing and searching for data, (3) examining the triangulation of data sources or triangulation of methods to check the validity of data regarding to the policy implementation of One-roof Elementary-Junior High School. To get valid data, researchers conducted a re-examination of the information obtained, for example when the school principal said that the community was not charged school fee, the researchers directly asked the parents and students if there was really no school fee to be paid by the students' parents to the schools. 
Jurnal Prima Edukasia, 8 (1), 2020 - 5

Wiwik Wijayanti

Transferability, this technique was employed to prove that the results of research on the implementation of the One-roof School in a particular setting could be transformed or transferred to another setting or situation. Basically, the application of transferability was an effort in to give detailed description; describing the contexts of research so that the results found could be understood by the other users. To make this transfer, the researcher looked for and collected empirical events about the similarities of contexts, in this case the events related to the research problem. This transferability was only possible when the subjects really had similarities in the contexts, not for general users because the conditions of each region could vary.

Dependability, because this research uses qualitative methods, the researcher herself was the key instrument, therefore this research can be categorized as dependable and validity, and can be justified scientifically. Therefore, its implementation required the process of the research accuracy acquisition test process that could provide specific considerations. This dependability was used to assess the process that researchers took and it was carried out by the dependent auditor. An audit of the findings of this study was carried out by promoters and informants who had been heavily involved in the One-roof Elementary-Junior High School. Through the process of coaching and consultation this was a means to get criticism and suggestions from the promoter, so that improvements could be made to enhance particular things.

Confirmability, this technique was employed for data checking in relation to the implementation of the One roof Primary and Junior High Schools. Additionally, various information of aspects surrounding them was obtained through observation and other data were also collected to ensure the validity of the research results. For example, regarding the teachers' qualifications, the school principal said that it was in accordance with their diplomas. The researcher conducted a check by looking at the teacher's data, and it was found that there were still teachers who did not teach in the same field of their field of expertise. Confirmability audit in this study was carried out concurrently with dependability audit, the difference was that confirmability was used to assess the process that would be taken until a research report was written. The core question of this conformability was on the relationship between data and information and interpretation in research reporting organizations.

\section{Results and Discussion}

The role of stakeholders in the implementation of the One-roof Elementary-Junior High School policy includes: (1) students' parents; (2) communities around the One-roof School; (3) school committees; (4) students; (5) teachers; (6) school principals; (7) the head of district education office; and (8) the head of Sub-district Education Affair Office. The stakeholders' support in the implementation of education was very much needed in order to realize the education goals. Without their involvement the learning process would be incomplete. For this reason, support from various parties as the stakeholders in education was needed. Each party had a role in accordance with their existence.

The Principal further stated that in the construction of one-roof school buildings, many community members were involved, they provided support in the form of energy and thoughts (based on the results of interview) "In the construction building, the community made a contribution of labor through community service and the builder were willing to be paid below the standard price which should be Rp. 25,000, but they agreed to be paid Rp. 20,000. The land had been granted by the village from the village treasury. It was actually a piece of land for the head of the village, but it was given to build the one-roof school. The people in charge were the village committee and authorities, the builder were the people from the village. Many people in those places were good builder.

The support needed by schools was not enough merely in the form of personnel or other material, but the awareness of parents to send their children to school and the participation/awareness of children to pursue/continue their education in junior high school level was very important. Because before the Bandungrejo Junior High School was built, it was very rare for the children there to continue their study to junior high school, as stated by the principal of the Islamic Elementary School of that area. The principal's explanation was likely true. It seemed that the economic condition of the family was the main reason for not sending their children to school. The lack of funds was the reason why children did not continue to attend school. The hardship of their parents was also experienced by several students in the school. They were at that time attending school because they were not charged with any education fee. 
Jurnal Prima Edukasia, 8 (1), 2020 - 6

Wiwik Wijayanti

If they had to pay for school, they would most likely not attend junior high school. The existence of Bandungrejo One-roof Elementary-Junior High School turned out to be helpful to raise parents' awareness in education.

Table 1. Comparison of circumstances between sites

\begin{tabular}{|c|c|c|c|}
\hline Focus & Site 1 (Bandungrejo) & Site 2 (Warangan) & Site 3 (Sanden) \\
\hline $\begin{array}{l}\text { Activities in } \\
\text { planning }\end{array}$ & $\begin{array}{l}\text { Looked for students' data, } \\
\text { teachers' data, infrastructure } \\
\text { data, requested village land } \\
\text { grants (when the proposal was } \\
\text { submitted), gathered } \\
\text { community support }\end{array}$ & $\begin{array}{l}\text { Looked for students' data, } \\
\text { teachers' data, } \\
\text { infrastructure data, } \\
\text { requested village land } \\
\text { grants (when the proposal } \\
\text { was submitted), gathered } \\
\text { community support }\end{array}$ & $\begin{array}{l}\text { Looked for students' data, } \\
\text { teachers' data, } \\
\text { infrastructure data, } \\
\text { requested village land } \\
\text { grants (when the proposal } \\
\text { was submitted), gathered } \\
\text { community support }\end{array}$ \\
\hline $\begin{array}{l}\text { Parties involved } \\
\text { in planning }\end{array}$ & $\begin{array}{l}\text { The principal assisted by the } \\
\text { teachers }\end{array}$ & $\begin{array}{l}\text { The principal assisted by } \\
\text { the teachers }\end{array}$ & $\begin{array}{l}\text { The principal assisted by } \\
\text { the teachers }\end{array}$ \\
\hline Planning process & $\begin{array}{l}\text { Based on teacher concerns, } \\
\text { there were opportunities and } \\
\text { guidance given from the Sub- } \\
\text { district Education Affair } \\
\text { Department. Then proposals } \\
\text { were made, and sent to } \\
\text { districts and provinces } \\
\text { authorities, waiting for } \\
\text { verification and approval. }\end{array}$ & $\begin{array}{l}\text { Based on teacher concerns, } \\
\text { there were opportunities } \\
\text { and guidance given from } \\
\text { the Sub-district Education } \\
\text { Affair Department. Then } \\
\text { proposals were made, and } \\
\text { sent to districts and } \\
\text { provinces authorities, } \\
\text { waiting for verification and } \\
\text { approval. }\end{array}$ & $\begin{array}{l}\text { Based on teacher concerns, } \\
\text { there were opportunities } \\
\text { and guidance given from } \\
\text { the Sub-district Education } \\
\text { Affair Department. Then } \\
\text { proposals were made, and } \\
\text { sent to districts and } \\
\text { provinces authorities, } \\
\text { waiting for verification and } \\
\text { approval. }\end{array}$ \\
\hline $\begin{array}{l}\text { Socialization } \\
\text { process }\end{array}$ & $\begin{array}{l}\text { Inviting community leaders } \\
\text { (heads \& village apparatuses, } \\
\text { principals of } \\
\text { Elementary/Islamic } \\
\text { Elementary Schools, teachers, } \\
\text { school committees) }\end{array}$ & $\begin{array}{l}\text { Inviting community } \\
\text { leaders (heads \& village } \\
\text { apparatuses, principals of } \\
\text { Elementary / Islamic } \\
\text { Elementary Schools, } \\
\text { teachers, school } \\
\text { committees) }\end{array}$ & $\begin{array}{l}\text { Inviting community } \\
\text { leaders (heads \& village } \\
\text { apparatuses, principals of } \\
\text { Elementary / Islamic } \\
\text { Elementary Schools, } \\
\text { teachers, school } \\
\text { committees) }\end{array}$ \\
\hline $\begin{array}{l}\text { The parties } \\
\text { involved in the } \\
\text { socialization }\end{array}$ & $\begin{array}{l}\text { Principals, teachers, village } \\
\text { heads, village leaders, } \\
\text { community leaders, } \\
\text { community members. }\end{array}$ & $\begin{array}{l}\text { Principals, teachers, } \\
\text { village heads, village } \\
\text { leaders, community } \\
\text { leaders, community } \\
\text { members. }\end{array}$ & $\begin{array}{l}\text { Principals, teachers, } \\
\text { village heads, village } \\
\text { leaders, community } \\
\text { leaders, community } \\
\text { members. }\end{array}$ \\
\hline $\begin{array}{l}\text { Target of } \\
\text { socialization }\end{array}$ & $\begin{array}{l}\text { Community members and } \\
\text { students }\end{array}$ & $\begin{array}{l}\text { Community members and } \\
\text { students }\end{array}$ & $\begin{array}{l}\text { Community members and } \\
\text { students }\end{array}$ \\
\hline Media outreach & $\begin{array}{l}\text { Meetings, brochures and } \\
\text { directly told news }\end{array}$ & $\begin{array}{l}\text { Meetings, brochures and } \\
\text { directly told news }\end{array}$ & $\begin{array}{l}\text { Meetings, brochures and } \\
\text { directly told news }\end{array}$ \\
\hline $\begin{array}{l}\text { Result of } \\
\text { socialization }\end{array}$ & $\begin{array}{l}\text { Parents had awareness; } \\
\text { children were excited }\end{array}$ & $\begin{array}{l}\text { Parents had awareness; } \\
\text { children were excited }\end{array}$ & $\begin{array}{l}\text { Parents had awareness; } \\
\text { children were excited }\end{array}$ \\
\hline $\begin{array}{l}\text { The } \\
\text { collaboration } \\
\text { between } \\
\text { Elementary- } \\
\text { Junior High } \\
\text { School }\end{array}$ & $\begin{array}{l}\text { There were elementary school } \\
\text { classrooms used for junior } \\
\text { high school classrooms, } \\
\text { elementary school teachers } \\
\text { motivated students to continue } \\
\text { attending higher level of } \\
\text { education }\end{array}$ & $\begin{array}{l}\text { There were elementary } \\
\text { school classrooms used for } \\
\text { junior high school } \\
\text { classrooms, elementary } \\
\text { school teachers motivated } \\
\text { students to continue } \\
\text { attending higher level of } \\
\text { education }\end{array}$ & $\begin{array}{l}\text { There were elementary } \\
\text { school classrooms used for } \\
\text { junior high school } \\
\text { classrooms, elementary } \\
\text { school teachers motivated } \\
\text { students to continue } \\
\text { attending higher level of } \\
\text { education }\end{array}$ \\
\hline $\begin{array}{l}\text { The } \\
\text { collaboration } \\
\text { between the }\end{array}$ & $\begin{array}{l}\text { The construction of the } \\
\text { building was handed over to } \\
\text { the committee, the community } \\
\text { members contributed labor, }\end{array}$ & $\begin{array}{l}\text { The construction of the } \\
\text { building was handed over } \\
\text { to the committee, the } \\
\text { community members }\end{array}$ & $\begin{array}{l}\text { The construction of the } \\
\text { building was handed over } \\
\text { to the committee, the } \\
\text { community members }\end{array}$ \\
\hline
\end{tabular}


Jurnal Prima Edukasia, 8 (1), 2020 - 7

Wiwik Wijayanti

\begin{tabular}{|c|c|c|c|}
\hline Focus & Site 1 (Bandungrejo) & Site 2 (Warangan) & Site 3 (Sanden) \\
\hline $\begin{array}{l}\text { Elementary } \\
\text { School-village }\end{array}$ & $\begin{array}{l}\text { the wages of the builder were } \\
\text { below the standard, the land } \\
\text { used was a donation from the } \\
\text { village treasury }\end{array}$ & $\begin{array}{l}\text { contributed labor, the } \\
\text { wages of the builder were } \\
\text { below the standard, the } \\
\text { land used was a donation } \\
\text { from the village treasury }\end{array}$ & $\begin{array}{l}\text { contributed labor, the } \\
\text { wages of the builder were } \\
\text { below the standard, the } \\
\text { land used was a donation } \\
\text { from the village treasury }\end{array}$ \\
\hline curriculum & $\begin{array}{l}\text { The basis of national } \\
\text { curriculum learning }\end{array}$ & $\begin{array}{l}\text { The basis of national } \\
\text { curriculum learning }\end{array}$ & $\begin{array}{l}\text { The basis of national } \\
\text { curriculum learning }\end{array}$ \\
\hline $\begin{array}{l}\text { Teachers' } \\
\text { condition }\end{array}$ & $\begin{array}{l}\text { There were } 11 \text { teachers, } 2 \text { of } \\
\text { which did not have suitable } \\
\text { diploma for the lesson taught. }\end{array}$ & $\begin{array}{l}\text { There were } 29 \text { teachers, } 2 \\
\text { of which did not have } \\
\text { suitable diploma for the } \\
\text { lesson taught. }\end{array}$ & $\begin{array}{l}\text { There were } 10 \text { teachers } \\
\text { and they had suitable } \\
\text { diploma qualifications. }\end{array}$ \\
\hline $\begin{array}{l}\text { Administration } \\
\text { Staff Conditions }\end{array}$ & $\begin{array}{l}\text { The number of } \\
\text { administrations staff was } 1 \\
\text { person and } 1 \text { guard }\end{array}$ & $\begin{array}{l}\text { There were } 3 \\
\text { administrations staff and } 1 \\
\text { guard }\end{array}$ & $\begin{array}{l}\text { There were } 2 \\
\text { administration staffs, } 1 \\
\text { guard and } 1 \text { librarian }\end{array}$ \\
\hline $\begin{array}{l}\text { Students' } \\
\text { condition }\end{array}$ & $\begin{array}{l}4 \text { classes; class } 7=2 \text {, class } 8 \\
=2, \text { there were } 148 \text { students } \\
\text { in total }\end{array}$ & $\begin{array}{l}6 \text { classes, class } 7=2 \text {, class } \\
8=2 \text { and class } 9=2, \text { there } \\
\text { were } 127 \text { students in total }\end{array}$ & $\begin{array}{l}3 \text { classes; class } 7=1 \text {, class } \\
8=2, \text { there were } 81 \\
\text { students in total }\end{array}$ \\
\hline $\begin{array}{l}\text { The condition of } \\
\text { the school } \\
\text { building }\end{array}$ & $\begin{array}{l}3 \text { classrooms }+1 \text { elementary } \\
\text { school }\end{array}$ & $\begin{array}{l}3 \text { classes }+3 \text { elementary } \\
\text { schools }\end{array}$ & 3 classrooms. \\
\hline $\begin{array}{l}\text { The role of } \\
\text { students' parents }\end{array}$ & $\begin{array}{l}\text { Allowing and encouraging } \\
\text { children to attend the school } \\
\text { because it was close and free. }\end{array}$ & $\begin{array}{l}\text { Allowing and encouraging } \\
\text { children to attend the } \\
\text { school because it was close } \\
\text { and free. }\end{array}$ & $\begin{array}{l}\text { Allowing and encouraging } \\
\text { children to attend the } \\
\text { school because it was close } \\
\text { and free. }\end{array}$ \\
\hline $\begin{array}{l}\text { The role of the } \\
\text { surrounding } \\
\text { community }\end{array}$ & $\begin{array}{l}\text { Donating labor in building } \\
\text { construction, having } \\
\text { awareness in education }\end{array}$ & $\begin{array}{l}\text { Donating labor in building } \\
\text { construction, having } \\
\text { awareness in education }\end{array}$ & $\begin{array}{l}\text { Donating labor in building } \\
\text { construction, having } \\
\text { awareness in education }\end{array}$ \\
\hline $\begin{array}{l}\text { The role of the } \\
\text { school } \\
\text { committee }\end{array}$ & $\begin{array}{l}\text { The organizer of the school } \\
\text { development and motivator of } \\
\text { the community }\end{array}$ & $\begin{array}{l}\text { The organizer of the } \\
\text { school development and } \\
\text { motivator of the } \\
\text { community }\end{array}$ & $\begin{array}{l}\text { The organizer of the } \\
\text { school development and } \\
\text { motivator of the } \\
\text { community }\end{array}$ \\
\hline Students' role & $\begin{array}{l}\text { Attending the class and } \\
\text { studying diligently }\end{array}$ & $\begin{array}{l}\text { Attending the class and } \\
\text { studying diligently }\end{array}$ & $\begin{array}{l}\text { Attending the class and } \\
\text { studying diligently }\end{array}$ \\
\hline $\begin{array}{l}\text { The role of the } \\
\text { principals }\end{array}$ & $\begin{array}{l}\text { Empowering human } \\
\text { resources, establishing } \\
\text { harmonious communication, } \\
\text { leading two institutions, } \\
\text { coordinating learning } \\
\text { activities }\end{array}$ & $\begin{array}{l}\text { Empowering human } \\
\text { resources, establishing } \\
\text { harmonious } \\
\text { communication, leading } \\
\text { two institutions, } \\
\text { coordinating learning } \\
\text { activities }\end{array}$ & $\begin{array}{l}\text { Empowering human } \\
\text { resources, establishing } \\
\text { harmonious } \\
\text { communication, leading } \\
\text { two institutions, } \\
\text { coordinating learning } \\
\text { activities }\end{array}$ \\
\hline $\begin{array}{l}\text { The role of the } \\
\text { district office }\end{array}$ & As the consultant & As the consultant & As the consultant \\
\hline $\begin{array}{l}\text { The role of Sub- } \\
\text { district education } \\
\text { Affair Office }\end{array}$ & Giving the guidance & Giving the guidance & Giving the guidance \\
\hline
\end{tabular}

The growing awareness of parents and children about education was apparently the fruit gained from the participation of community leaders. One of the community leaders had a big role in fostering awareness of the residents around the village of Bandungrejo. She tried to convince the local people as what she said on this commentary "At the very least I have started from our family. My son, thank God, was able to go to the university. However, I warn son that even though you're a college student now, you should remain polite mainly to the residents here, do not feel that you are the cleverest, do not ever forget to behave. Now for families around this neighborhood, if the economy is considered as rather 
Jurnal Prima Edukasia, 8 (1), 2020 - 8

Wiwik Wijayanti

steady, I encourage them to send their children to school, to continue more than junior high school level. Do not worry too much about the tuition fee, while the children are studying there must be a way to pay for it."

The involvement of various parties and the availability of supporting data were needed in planning the One Roof Elementary-Junior High School in isolated, remote and scattered regions.

One roof School is a new education policy in compulsory education framework, intended for Elementary School/Islamic Elementary school graduates who were not accommodated because they lived in isolated, remote and scattered areas. In order to build the One-roof School in the mentioned location, some plans were needed. The planning carried out was seen in the process of proposal making. In fact, teachers and the community had long wanted to have a junior high school in their area, due to the fact that many elementary school graduates did not continue their education. Based on the facts mentioned above, it was clear that local people really needed education development. Therefore, plans were made based on the community needs. According to (Usman, 2004, p. 64) planning that is made based on the community needs is called planning with a social demand approach. A program planning will be in vain if it is not in line with the needs of the community. This One-roof Elementary-Junior High School was built because of the community needs, where many children did not continue their education to junior high school level.

These three one-roof schools (Bandungrejo, Warangan and Sanden) had the same backgrounds in which many elementary graduates did not continue their education. This occurred because the condition of the areas that were located in remote, isolated and scattered areas far from any junior high school. Furthermore, the students' financial condition seemed that it would be hard for their family to pay their education fee. They could only meet the very basic necessities of life such as food, clothing and shelter with improper conditions. No wonder they lacked in awareness or did not interested at all in sending their children to junior high school. This fact makes the principals had the desire to build junior high school in that areas. Apparently, what had been whished was granted. There was information from the Magelang District Education Office and the sub-district Education Office (Ngablak, Pakis and Sawangan), that there were opportunities to submit requests to establish one-roof schools.

After receiving information from the Education Department and Sub-district Office that there ware opportunities to submit proposals, the elementary school principals assisted by the teachers started to collect data and support as a requirement in making the proposals. In making the proposals, it was necessary to be able to analyze the situation and utilized existing human resources. Therefore, principals who had visions for the future would be advantageous. As stated by Cotarda (Danim \& Suparno, 2009, p. 134) a vision is "a view of our environment that will enable our tremendous future success ". This definition implies that meaningful success in the future is largely determined by the peoples' ability in looking at the environment carefully, because environmental factors determine the success to reach the bright future.

In making the proposals the Elementary School Principals were assisted by teachers in collecting data and support from the surrounding community voluntarily without any coercion. Empowerment or the provision of opportunities and or encouraging all people in the school (teachers, students, teaching staff and students, parents, communities, etc.) willingly, without coercion, to participate optimally in order to achieve school goals is the characteristic of transformational leadership (Danim \& Suparno, 2009, p. 53). Transformative leaders are more "motivating subordinates to do more rather than to do what is actually expected" or rather than just letting subordinates to follow the directions given. Usman (2004) added that transformative leaders are not super human, but those leaders who spark positive effects that can easily and pleasantly be accepted who can affect the whole organization and the people in it.

After the proposals were completed and had been authorized by the authorities, namely the Head of the Sub-district and the local Education Affair Office Head, the proposals were sent to the Regency and Province. Then there was a verification from the Province and Regency to see the feasibility of the program to be implemented. Because the proposals met the specified requirements then they were approved. After the approval, the committee was invited to a workshop to receive technical guidance on the use of funds and its mechanism. Warangan One Roof Elementary-Junior High School was established first (phase I) in 2007, while Bandungrejo and Sanden were established in 2008 (phase II).

The socialization was done to get understanding from the communities, it was expected that the community will respond positively. Residents of the surrounding community at three One Roof 
Jurnal Prima Edukasia, 8 (1), 2020 - 9

Wiwik Wijayanti

Elementary-Junior High Schools positively welcomed this program, this was seen from the increasing number of junior high school students. This proved the awareness of the community (parents) of education was growing, and students also had enthusiasm in learning. If we look at the economic condition of the family, this public awareness grew because parents were not burdened with school fees, and the distance was not far from home and the students even got free uniforms and shoes. However not all circumstances were like that. This happened because human behavior was influenced by motivation both from inside (intrinsic) or from outside (extrinsic) (Zimmerman \& Schunk, 2014). Without the burden of school fees (free), parents with low economic conditions were encouraged, and they had awareness to send their children to school (extrinsic motivation). On the contrary, there were also parents who did not mind to pay and to struggle with the great distance from school but they possessed already proper awareness to send their children to school (intrinsic motivation).

This approach is in line with the principles of complex adaptive systems. In complex adaptive systems things like, humans, environment, and the behavior of actors in a system interact to each other and the results of the interactions are difficult to predict. Each actor also often provides changing responses as part of their adaptation activities to the interaction. There is no static equilibrium here (http://www.positivedeviance.org). All elements in the education system from the students, educators, educational staff, infrastructure, curriculum, funds and stakeholders interact to each other, understand and carry out their duties and authority, so that each element can adjust, balance themselves for the realization of quality education.

Positive deviance is based on the observation that in every community there are certain individuals or groups whose uncommon behaviors and strategies enable them to find better solutions to problems than their peers, while having access to the same resources and facing similar or worse challenges. The positive deviance approach emphasizes learning from the system itself by looking for certain behaviors that are already successful in the complex system. Then, then the existing solution is spread into the system. Because the solution comes from the system itself, the system will be more tolerant of the solution when applied on a broader scale. In short, the approach of positive deviance is a problem-solving approach that emphasizes learning (learning) than teaching (teaching).

Adopting (Marsh et al., 2004; Pascale \& Monique, 2010), it is expected from the community members who have an awareness of education even though they belong to the lower economic class to spread and invite other community members (neighbors) around them so that they have the same awareness in education. The rationalization of positive deviance is to look for reasons why there are some people who have the enthusiasm and awareness for schools even though their low economic conditions. The findings in this study indicates that parents from poor families can also have a high desire/ideal in education. This matter needs to be given attention and to be strived so that parents and children around the neighborhood have the desire/awareness even though they are from poor families.

Fullan $(2005,2007)$ states that the key factors in the process of implementing the policy are "9 critical factors organized into three categories relating to (1) the characteristics of the innovation or the project, (2) local roles, and (3) external factors. The group characteristics of change there include 4 elements, namely: needs, clarity, complexity and quality/practicality. Local characteristics group consists of 4 elements, namely: local conditions, community, school principals and teachers, and the external factors include the government and other providers.

The form of togetherness between the Junior High School and the village was seen in the implementation of the school buildings construction which were handed to the school committee. This is a form of devotedness from the village residents to the junior high school. Another form of togetherness was that the surrounding community members also contributed their labor, and what was more important was the land donation letter from the village. Without this land donation letter, the construction of the school buildings would not have been possible.

Meanwhile the form of togetherness in junior high school and elementary school was that some elementary school teachers who met the requirements willingly involved themselves to teach in junior high school. The teachers' need would be fulfilled gradually by the selection of civil servants. Elementary teachers tried to encourage students so that after graduating elementary school they wanted to continue to junior high school.

In the two institutions (elementary and junior high schools) it was seen that there was the existence of harmony and good cooperation between elementary and junior high school teachers, both between elementary school teachers and middle school teachers, elementary school teachers and elementary 
Jurnal Prima Edukasia, 8 (1), 2020 - 10

Wiwik Wijayanti

school teachers and between middle school teachers and middle school teachers. Each elementary and junior high school teacher was responsible for the tasks they carry.

The establishment of One Roof Junior High School was useful to foster community awareness so that they had the intention to send their children to continue to junior high school without having to pay a lot of money. Likewise, the children/students felt happy because they could continue their study to junior high school so that they become more capable to prepare for their life in the future. Another benefit was to reduce unemployment rate by giving opportunities for teachers to be to teach in the schools.

The role of stakeholders according to their respective authorities and abilities was very meaningful to improve the school performance. Without their involvement, the One Roof ElementaryJunior High School could not have been carried out properly, both in the development process and in the learning process. Every element of stakeholders (students' parents, community, committee, Principal, Head of Sub-district Education Office, and Head of Regency Office) had a role in accordance with their existence. All supported each other for the implementation of the One Roof Elementary-Junior High School program.

Article 8 of the 2003 National Education System Law states that the community has the right to participate in the planning, implementation, supervision and evaluation of educational programs. Furthermore, Article 9 states that the community is obliged to provide support for resources in the administration of education. This shows how important community participation in education policy is, because education is organized from, by and for the people. According to (Imran, 2008) community participation is the object of development. What is built is not only physical and mental problems but also the development of community participation.

The role of stakeholders (community participation) in education can be manifested in various forms, in accordance with their respective authorities and abilities. Thoha (1984) classifies community participation into three, namely: (1) independent participation which is a participatory effort carried out independently by the perpetrators, (2) mobilization participation, and (3) ceremonial participation. Whereas Muhadjir (Imran, 2008) classifies community participation into his typology, namely quantitative participation and qualitative participation. Quantitative participation refers to the frequency of participation in policy implementation, while qualitative participation refers to the level and degree.

The participation of stakeholders in the implementation of the policy is not only seen as people's loyalty to the government, but what is very important is that the community considers that the policy is its own. With a sense of belonging to the implementation of the policy, there will be more donations given by the community. This is a form of empowerment and utilization of the capital of basic development.

\section{Conclusion}

The role of stakeholders (community participation) in education can be manifested in various forms, in accordance with their respective authorities and abilities. Stakeholder involvement can be in the forms of; labor, ideas, and material (things). Awareness of sending children to school is also a form of community participation. Conclusions in detail are as follows; First, stakeholders act according to their portion; Second, parents have the awareness of sending them to school and encouraging their children to want to continue schooling; Third, the surrounding community participates in the construction of buildings, collaborating to contribute labor; sub-standard wage agreements, as a form of community awareness and contribution to the One Roof Junior Secondary School; Fourth, student participation is needed in organizing the learning process and school development plans; Fifth, teachers work together and carry out tasks according to their authority; Sixth, the Principal coordinates the activities in elementary and junior high schools; Seventh, the Head of UPT facilitated the process of proposing the establishment of SMP; Eighth, Head of the Elementary and Secondary Education Section as a consultant in the implementation of the One Roof Junior Secondary School.

\section{References}

Abu-Duhou, I., \& Fadjar, M. (2002). School based management (N. Aini (trans.)). LOGOS Wacana Ilmu dan Pendidikan.

Bafadal, I. (2007). Pendidikan dasar: Kontribusi, artikulasi, regulasi, aktualisasi, reorientasi, dan 
akselerasi. In Pidato pengukuhan Guru Besar Fakultas Ilmu Pendidikan. Universitas Negeri Malang.

Bogdan, R., \& Biklen, S. K. (2003). Qualitative research for education : an introduction to theory and methods. Allyn and Bacon.

Danim, S., \& Suparno, D. (2009). Manajemen dan kepemimpinan transformasional kekepalasekolahan: Visi dan strategi sukses era teknologi, situasi krisis, dan internasionalisasi pendidikan. Rineka Cipta.

Darmayanti, S. E., \& Wibowo, U. B. (2014). Evaluasi program pendidikan karakter di sekolah dasar Kabupaten Kulon Progo. Jurnal Prima Edukasia, 2(2), 223-234. https://doi.org/10.21831/jpe.v2i2.2721

Departemen Pendidikan Nasional Republik Indonesia. (2007). Panduan pelaksanaan pengembangan SD-SMP Satu Atap, program Australia-Indonesia Basic Education Program (AIBEP). Ditjen Mandikdasmen.

Fullan, M. (2005). The meaning of educational change: A quarter of a century of learning. In The Roots of Educational Change (pp. 202-216). Springer Netherlands. https://doi.org/10.1007/1-40204451-8_12

Fullan, M. (2007). The new meaning of educational change. Routledge.

Guba, E. G., \& Lincoln, Y. S. (2004). Competing paradigms in qualitative research: Theories and issues. In Approaches to qualitative research: A reader on theory and practice (pp. 17-38). Oxford University Press.

Imran, A. (2008). Kebijaksanaan pendidikan di Indonesia; Proses, produk, dan masa depannya. Bumi Aksara.

Lincoln, Y. S., \& Guba, E. G. (1985). Naturalistic inquiry. Sage Publications. https://books.google.co.id/books/about/Naturalistic_Inquiry.html?id=2oA9aWlNeooC\&redir_es $\mathrm{c}=\mathrm{y}$

Marsh, D. R., Schroeder, D. G., Dearden, K. A., Sternin, J., \& Sternin, M. (2004). The power of positive deviance. BMJ, 329(7475), 1177-1179. https://doi.org/10.1136/bmj.329.7475.1177

Miles, M. B., Huberman, A. M., \& Saldaña, J. (2014). Qualitative data analysis: A methods sourcebook. Sage.

Moleong, L. J. (2013). Metodologi penelitian kualitatif (Ed. Rev.). PT Remaja Rosdakarya. https://doi.org/2010

Pascale, R., \& Monique, S. J. S. (2010). The power of positive deviance. Harvard Business Press.

Undang-Undang Republik Indonesia nomor 20 tahun 2003 tentang sistem pendidikan nasional, Pub. L. No. 20, Undang-Undang Republik Indonesia 26 (2003).

Sugiyono, S. (2005). Metode penelitian administrasi. Alfabeta.

Sutisna, O. (1987). Administrasi pendidikan: Dasar, teori dan praktek profesional. Angkasa.

Thoha, M. (1984). Dimensi-dimensi prima ilmu administrasi negara. Rajawali.

Tilaar, H. A. R. (2000). Paradigma baru pendidikan nasional. Rineka Cipta.

Usman, H. (2004). Manajemen pendidikan. Pascasarjana Universitas Negeri Yogyakarta.

Zimmerman, B. J., \& Schunk, D. H. (2014). Educational psychology. Routledge. https://doi.org/10.4324/9781315734255 